\title{
Calcium wave signaling in cancer cells
}

\author{
JAI PARKASH ${ }^{\mathrm{a}}$ and KAMLESH ASOTRA ${ }^{\mathrm{b}}$ \\ aRobert Stempel College of Public Health and Social Work, Department of Environmental and \\ Occupational Health, Florida International University, 11200 SW $8^{\text {th }}$ Street, HLS-594, Miami, FL \\ 33199, USA \\ bTobacco-Related Disease Research Program University of California Office of President 300 \\ Lakeside Drive Oakland, CA 94612, USA Tel: (510) 287-3366 FAX: (510) 835-4740 \\ kamlesh.asotra@ucop.edu
}

\begin{abstract}
$\mathrm{Ca}^{2+}$ functions as an important signaling messenger right from beginning of the life to final moment of the end of the life. $\mathrm{Ca}^{2+}$ is needed at several steps of the cell cycle such as early $\mathrm{G}_{1}$, at the $\mathrm{G}_{1} / \mathrm{S}$, and $\mathrm{G}_{2} / \mathrm{M}$ transitions. The $\mathrm{Ca}^{2+}$ signals in the form of time-dependent changes in intracellular $\mathrm{Ca}^{2+}$ concentrations, $\left[\mathrm{Ca}^{2+}\right]_{i}$, are presented as brief spikes organized into regenerative $\mathrm{Ca}^{2+}$ waves. $\mathrm{Ca}^{2+}$-mediated signaling pathways have also been shown to play important roles in carcinogenesis such as transformation of normal cells to cancerous cells, tumor formation and growth, invasion, angiogenesis and metastasis. Since the global $\mathrm{Ca}^{2+}$ oscillations arise from $\mathrm{Ca}^{2+}$ waves initiated locally, it results in stochastic oscillations because although each cell has many $\mathrm{IP}_{3} \mathrm{Rs}$ and $\mathrm{Ca}^{2+}$ ions, the law of large numbers does not apply to the initiating event which is restricted to very few $\mathrm{IP}_{3} \mathrm{Rs}$ due to steep $\mathrm{Ca}^{2+}$ concentration gradients. The specific $\mathrm{Ca}^{2+}$ signaling information is likely to be encoded in a calcium code as the amplitude, duration, frequency, waveform or timing of $\mathrm{Ca}^{2+}$ oscillations and decoded again at a later stage. Since $\mathrm{Ca}^{2+}$ channels or pumps involved in regulating $\mathrm{Ca}^{2+}$ signaling pathways show altered expression in cancer, one can target these $\mathrm{Ca}^{2+}$ channels and pumps as therapeutic options to decrease proliferation of cancer cells and to promote their apoptosis. These studies can provide novel insights into alterations in $\mathrm{Ca}^{2+}$ wave patterns in carcinogenesis and lead to development of newer technologies based on $\mathrm{Ca}^{2+}$ waves for the diagnosis and therapy of cancer.
\end{abstract}

\section{Keywords}

Apoptosis; Calcium; Cancer; Cell cycle; Metastasis; Oscillations; Signaling; Stochastic; Wave

\section{Introduction}

At the beginning of life, $\mathrm{Ca}^{2+}$ mediates the process of fertilization as well as regulates the cell cycle events during the early developmental processes. Once the cells differentiate to perform specific functions, $\mathrm{Ca}^{2+}$ regulates several processes as diverse as energy

(C) 2010 Elsevier Inc. All rights reserved

Correspondence: Jai Parkash, Ph.D., Assistant Professor, Robert Stempel College of Public Health and Social Work, Department of Environmental and Occupational Health, Florida International University, $11200 \mathrm{SW} 8^{\text {th }}$ Street, Room: HLS-594, Miami, FL 33199, USA Phone: (305) 348-7791: Fax: (305) 348-4901 parkashj@fiu.edu.

Publisher's Disclaimer: This is a PDF file of an unedited manuscript that has been accepted for publication. As a service to our customers we are providing this early version of the manuscript. The manuscript will undergo copyediting, typesetting, and review of the resulting proof before it is published in its final citable form. Please note that during the production process errors may be discovered which could affect the content, and all legal disclaimers that apply to the journal pertain. 
transduction, secretions, apoptosis, muscle contraction, chemotaxis and neuronal synaptic plasticity in learning and memory (Berridge 2009; Berridge et al. 2003; Clapham 2007; Mikoshiba 2007). Since $\mathrm{Ca}^{2+}$ ions are toxic to the cells, the intracellular concentration of $\mathrm{Ca}^{2+},\left[\mathrm{Ca}^{2+}\right]_{\mathrm{i}}$, in resting cells is usually maintained very low at $\sim 100 \mathrm{nM}$. While in normal salt solution, the hydrated $\mathrm{Ca}^{2+}$ can diffuse $40 \mu \mathrm{m}$ in $1 \mathrm{sec}$ (Einstein 1905); in cells, due to the presence of several charged molecules, the $\mathrm{Ca}^{2+}$ diffusion rates are slower. In order to utilize $\mathrm{Ca}^{2+}$ as a second messenger, cells have devised an ingenious mechanism of signaling that has overcome the inherent problems associated with lower diffusion rates and cytotoxicity of $\mathrm{Ca}^{2+}$, by presenting changes in $\mathrm{Ca}^{2+}$ concentration as brief spikes which are often organized as regenerative waves (Berridge 1993; Clapham 2007; Rey et al. 2010).

To provide for a very fast and effective $\mathrm{Ca}^{2+}$-signaling, the cells use a great amount of energy to maintain almost 20000 -fold $\mathrm{Ca}^{2+}$-gradient between their intracellular $(\sim 100 \mathrm{nM}$ free) and extracellular $(\sim 1.2 \mathrm{mM}) \mathrm{Ca}^{2+}$ concentrations. To maintain this 20000 -fold $\mathrm{Ca}^{2+}$ gradient, the cells chelate, compartmentalize, or remove $\mathrm{Ca}^{2+}$ from the cytoplasm (Clapham 2007). Various cellular proteins with $\mathrm{Ca}^{2+}$ - binding affinities ranging between $\mathrm{nM}$ to $\mathrm{mM}$ are utilized by the cells to buffer the cellular $\mathrm{Ca}^{2+}$ as well as to regulate cellular processes via $\mathrm{Ca}^{2+}$-signaling (see Fig. 1). The binding of $\mathrm{Ca}^{2+}$ to proteins can change protein conformations in terms of shape and charge, and thus modify its functions (Westheimer 1987). $\mathrm{Ca}^{2+}$-mediated signaling pathways have been shown to play important roles in cancer initiation, tumor formation, tumor progression, metastasis, invasion and angiogenesis (Block et al. 2010; Rizzuto and Pozzan 2006; Saidak et al. 2009). Some of the $\mathrm{Ca}^{2+}$-regulated pathways involved in cancers are briefly summarized in BOX 1.

Both the genetic and epigenetic mechanisms have been proposed for the specific roles of $\mathrm{Ca}^{2+}$ signaling in cancer (Hanahan and Weinberg 2000; Jaffe 2005). As a result of mutations, the normal cells can be transformed to cancerous cells by acquiring cancerspecific properties such as uncontrollable proliferation, immortality, and self-sufficiency in growth signals (Futreal et al. 2005; Hanahan and Weinberg 2000). Since $\mathrm{Ca}^{2+}$-gradients and waves have been shown to be involved in normal developmental processes, the epigenetic theory proposes that altered $\mathrm{Ca}^{2+}$-gradients and waves participate in carcinogenesis (Jaffe 2005). The intracellular $\mathrm{Ca}^{2+}$ waves in concert with various other signal-transduction cascades, regulate a variety of processes including gene expression (De Koninck and Schulman 1998; Dolmetsch 2003; Dolmetsch et al. 1998). The intracellular $\mathrm{Ca}^{2+}{ }_{\text {-induced }}$ activation of protein kinase $\mathrm{C}(\mathrm{PKC})$ can lead to phosphorylation of methyltransferase that is involved in DNA methylation (DePaoli-Roach et al. 1986). In normal cells, $\mathrm{Ca}^{2+}$ - signaling is required for cell proliferation, whereas some transformed cells and tumor cell lines show altered dependency on $\mathrm{Ca}^{2+}$ to maintain proliferation (Cook and Lockyear 2006; Whitfield 1992). $\mathrm{Ca}^{2+}$ - signaling pathways are remodeled or deregulated in cancer that result in changes in their physiology and distinguish them from non-malignant cells (Hanahan and Weinberg 2000; Wang et al. 2010). Remodeling or deregulation of $\mathrm{Ca}^{2+}$ - signaling pathways can provide means by which cancer cells can overcome systemic anticancer defense mechanisms. The altered $\mathrm{Ca}^{2+}$ - signaling pathways can also lead to genetic diversity found in cancerous tissues thereby providing effective cellular strategies to the selection pressure to acquire specific traits.

In this review, we first describe our present understanding of $\mathrm{Ca}^{2+}$ - signaling in cells including $\mathrm{Ca}^{2+}$ fluxes across the plasma membrane, $\mathrm{Ca}^{2+}$ translocation across the ER, wave nature of $\mathrm{Ca}^{2+}$ signals, and the role of various $\mathrm{Ca}^{2+}$ binding proteins followed by extensive discussion on the role of $\mathrm{Ca}^{2+}$ signaling in cancer cells proliferation and apoptosis (Berridge 2005; Carafoli 2004; Petersen 2005; Rizzuto and Pozzan 2006). 


\section{Box 1: $\mathrm{Ca}^{2+}$ and cancer}

The cells maintain a 20000 -fold gradient of $\mathrm{Ca}^{2+}$ between extracellular free $\mathrm{Ca}^{2+}(\sim 1.2$ $\mathrm{mM})$ and resting cytoplasmic free $\mathrm{Ca}^{2+}(\sim 100 \mathrm{nM})$. Depending upon the stimulus, $\left[\mathrm{Ca}^{2+}\right]_{\mathrm{i}}$ can exceed more than $1 \mu \mathrm{M}$ (Rizzuto and Pozzan 2006; Rizzuto et al. 2003). The spatio-temporal nature of changes in the free $\mathrm{Ca}^{2+}$ can regulate many cellular processes including cancer initiation, progression, angiogenesis, and metastasis as described below (Rizzuto and Pozzan 2006; Rizzuto et al. 2003; Saidak et al. 2009):

\section{Transcription}

The changes in $\mathrm{Ca}^{2+}$ wave oscillation frequency can activate transcription factors such as nuclear factor of activated T cells (NFAT) resulting in modulation of cellular transcription (Carafoli 2002; Dolmetsch 2003; Rizzuto and Pozzan 2006). Experiments using the "calcium clamp" have shown that the sensitivity of different transcription factors to $\left[\mathrm{Ca}^{2+}\right]_{\mathrm{i}}$ oscillations is highly frequency dependent (Dolmetsch et al. 1997; Lewis 2003).

\section{Cell cycle}

Since $\mathrm{Ca}^{2+}$ regulates the cell cycle at several stages, it is involved in cell proliferation through various signaling pathways (Cullen and Lockyer 2002; Ding et al. 2010; Minaguchi et al. 2006; Rey et al. 2010; Zhong et al. 2010). The $\mathrm{Ca}^{2+}$-induced activation of the transcription of early genes is involved in the transition from $G_{0}$ to $G_{1}$. The subcellular localization of key proteins associated with cell cycle and carcinogenesis is influenced by $\mathrm{Ca}^{2+}$ (Cook and Lockyer 2006). $\mathrm{Ca}^{2+}$ has been shown to regulate the phosphorylation of retinoblastoma protein in late G1 phase (Cook and Lockyer 2006).

\section{Genotoxicity}

$\mathrm{Ca}^{2+}$ can modulate poly-(ADP-ribose) polymerase-1 (PARP1) as well as DNA damage response pathways which in turn can influence genomic stability and cell survival (Bentle et al. 2006).

\section{Differentiation}

Cancer cells can become dedifferentiated into cancer stem cells in the tumorigenic process, and $\mathrm{Ca}^{2+}$ signaling is implicated in the differentiation process either through the extracellular $\mathrm{Ca}^{2+}$-sensing receptor and/or through alterations in intracellular $\mathrm{Ca}^{2+}($ Bikle et al. 2004).

\section{Angiogenesis}

By mobilizing release of $\mathrm{Ca}^{2+}$ from ER, angiogenic factors such as vascular endothelial growth factor can increase $\left[\mathrm{Ca}^{2+}\right]_{\mathrm{i}}$ and therefore induce $\mathrm{Ca}^{2+}$ signaling that in turn plays critical roles in angiogenesis (Munaron and Fiorio 2009; Patton et al. 2003).

\section{Telomerase}

Cancer cells upregulate telomerase expression in order to maintain their telomeres for cellular immortality. The $\mathrm{Ca}^{2+}$ binding protein $\mathrm{S} 100 \mathrm{~A} 8$ can inhibit the activity of telomerase (Rosenberger et al. 2007).

\section{Motility}

$\mathrm{Ca}^{2+}$ has been associated with motility for a long time since Sidney Ringer found that it was the $\mathrm{Ca}^{2+}$ in London's "hard" tap water that was required for heart contraction (Ringer 1883). 
The intracellular $\mathrm{Ca}^{2+}$ signaling plays important role in cellular motility such as during tumor invasion and metastasis, the extracellular $\mathrm{Ca}^{2+}$ signaling has been shown to be associated with bone metastasis (Amuthan et al. 2002; Berridge et al. 2003; Huang et al. 2004; Zhong et al. 2010).

\section{Apoptosis}

The increase in $\left[\mathrm{Ca}^{2+}\right]_{\mathrm{i}}$ and $\left[\mathrm{Ca}^{2+}\right]_{\text {mito }}$ and the activation of mitochondrial membrane permeabilization can lead to apoptosis and necrosis (Rizzuto and Pozzan 2006; Rizzuto et al. 2003). Similarly, a decrease in the $\mathrm{Ca}^{2+}$ content of the lumen of the $\mathrm{ER}$ is associated with resistance to apoptosis (Rizzuto et al. 2003; Pinton and Rizzuto 2006).

\section{$\mathrm{Ca}^{2+}$ signaling initiation}

In order to maintain low $\left[\mathrm{Ca}^{2+}\right]_{\mathrm{i}}$, the ATPase pump such as sarcoendoplasmic reticular $\mathrm{Ca}^{2+}$ ATPase (SERCA) pumps in $\mathrm{Ca}^{2+}$ - into ER by exchanging protons for two $\mathrm{Ca}^{2+}$ per ATP hydrolyzed whereas plasma membrane $\mathrm{Ca}^{2+}$-ATPase (PMCA) removes $\mathrm{Ca}^{2+}$ by exchanging protons for $1 \mathrm{Ca}^{2+}$ per ATP hydrolyzed (Figure 1). In addition, the $\mathrm{Na}^{+} / \mathrm{Ca}^{2+}$ exchangers (NCX), and the $\mathrm{Na}^{+} / \mathrm{Ca}^{2+}-\mathrm{K}^{+}$exchangers (NCKX) exchange one $\mathrm{Ca}^{2+}$ ion for three $\mathrm{Na}^{+}$ ions or cotransport one $\mathrm{K}^{+}$ion with one $\mathrm{Ca}^{2+}$ ion in exchange for four $\mathrm{Na}^{+}$ions, respectively. In its "forward" mode, inward (depolarizing) $\mathrm{Na}^{+}$current drives $\mathrm{Ca}^{2+}$ extrusion from the cell. While the PMCAs are effective in maintaining low $\left[\mathrm{Ca}^{2+}\right]_{\mathrm{i}}$ over longer durations, NCX and NCKX function at a much faster rate to maintain low $\left[\mathrm{Ca}^{2+}\right]_{\mathrm{i}}$ (Hilgemann et al. 2006). Transient receptor potential (TRP) ion channels formed by tetrameric assembly around a pore, are weakly voltage-sensitive, nonselective ion channels (Goswami et al. 2010;Ramsey et al. 2006). TRP channels depolarize cells and increase intracellular $\mathrm{Na}^{+}$and $\mathrm{Ca}^{2+}$. TRP channels are greatly potentiated by phospholipase C (PLC) activation by G protein-coupled receptors (GPCRs) or tyrosine-kinase receptors (TKR).

The voltage dependent $\mathrm{Ca}^{2+}$ channels $(\mathrm{CaVs})$ are the fastest $\mathrm{Ca}^{2+}$ signaling proteins and each $\mathrm{CaV}$ channel conducts approximately one million $\mathrm{Ca}^{2+}$ ions per second down the 20 000 -fold gradient therefore a few thousand $\mathrm{CaV}$ channels/cell can increase $\left[\mathrm{Ca}^{2+}\right]_{\mathrm{i}}$ by more than 10 fold within milliseconds (Fig.1). A change in membrane potential opens the $\mathrm{CaV}$ "gate" and allows $\mathrm{Ca}^{2+}$ to move into the cytoplasm. In the presence of normal extracellular $\left[\mathrm{Ca}^{2+}\right]_{\mathrm{o}}$, the binding of $\mathrm{Ca}^{2+}$ to $\mathrm{CaV}$ provides ion selectivity to enter the pore (Gouaux and Mackinnon 2005;Long et al. 2005). However, when external $\mathrm{Ca}^{2+}$ is removed, these $\mathrm{Ca}^{2+}$ channels become nonselective and allow the entry of $\mathrm{Na}^{+}$and $\mathrm{K}^{+}$across the cell membrane. The increases in $\left[\mathrm{Ca}^{2+}\right]_{\mathrm{i}}$ can initiate translocation of several proteins, e.g., protein kinase $\mathrm{C}$ family proteins to specific regions of membranes. Another $\mathrm{Ca}^{2+}$-dependent membrane targeting scheme is used by annexins, where phosphoryl moieties of the membrane replace charge from carbonyl oxygens and water in a unique $\mathrm{Ca}^{2+}$-binding fold (Gerke et al. 2005).

The highly negatively charged phosphatidylinositol 4, 5-bisphosphate (PIP2) is bound to inner leaflets of plasma membranes by its acyl chains (see Fig.1). The positively charged residues on many peripheral and integral membrane proteins can attract negatively charged PIP2, leading to increase in the local concentration of PIP2 that attracts the positively charged proteins cluster close to the membrane. The negatively charged calmodulin present in the cytoplasm competes with PIP2 and may pull the positively charged protein segment off the membrane (McLaughlin and Murray 2005).

A universal mechanism for $\mathrm{Ca}^{2+}$ signaling is the release of $\mathrm{Ca}^{2+}$ from intracellular $\mathrm{Ca}^{2+}$ stores such as ER or SR (Fig.1). G-protein coupled receptors (GPCRs), primarily Gq/11 subtypes can activate phospholipase C $\beta$ (PLC $\beta$ ) and tyrosine kinase receptors (TKR) can activate PLC $\gamma$ which then cleave PIP2 into 1,4,5-inositol trisphosphate $\left(\mathrm{IP}_{3}\right)$ and 
diacylglycerol (DAG). $\mathrm{IP}_{3}$ binding to the $\mathrm{IP}_{3}$ receptors $\left(\mathrm{IP}_{3} \mathrm{R}\right)$ that are present in the ER causes efflux of $\mathrm{Ca}^{2+}$ from the ER to the cytoplasm resulting in increase in $\left[\mathrm{Ca}^{2+}\right]_{\mathrm{i}}$ from $\sim 100 \mathrm{nM}$ to $\sim 1 \mu \mathrm{M}$ for several seconds (Berridge 2009; Mikoshiba 2007). The binding of $\mathrm{Ca}^{2+}$ to the $\mathrm{C} 2$ domain of PKC $\alpha, \beta 1, \beta 2$, and $\gamma$ subtypes initiates translocation to the membrane, where coincident DAG binding activates it. $\mathrm{Ca}^{2+}$ - sensitive DAG kinase phosphorylates DAG to produce phosphatidic acid, while DAG lipase converts DAG to arachidonic acid. (Fig.1). $\mathrm{IP}_{3} \mathrm{R}$ mediated efflux of $\mathrm{Ca}^{2+}$ from the ER in response receptor activation empties the ER as PMCAs pump $\mathrm{Ca}^{2+}$ out of the cell faster than it can be repleted. Slowly over seconds after such store depletion, $\mathrm{a} \mathrm{Ca}^{2+}$ entry mechanism is activated. This mechanism is called store-operated $\mathrm{Ca}^{2+}$ entry (Putney 2005). A slow and tiny but highly selective $\mathrm{Ca}^{2+}$ conductance is activated when ER $\left[\mathrm{Ca}^{2+}\right]$ drops and it is called $\mathrm{Ca}^{2+}$-release activated current ( $\left.\mathrm{I}_{\mathrm{CRAC}}\right)$ (Parekh and Penner 1997).

$\mathrm{IP}_{3} \mathrm{Rs}$ are nonselective cationic channels that conduct $\mathrm{Ca}^{2+}$. The $\mathrm{IP}_{3} \mathrm{R}$ complex is a massive tetrameric channel with its pore formed by a homotetramers of $\sim 3,000$ amino acids. The six transmembrane-spanning domain is at the very $\mathrm{C}$-terminal end of each subunit, that provides for a large number of cytoplasmic regulatory sites and protein-binding domains. Regulated by an intrinsic suppressor domain, a hinged clamshell-like structure clasps $\mathrm{IP}_{3}$. Many proteins such as $\mathrm{IP}_{3} \mathrm{R}$-binding protein (IRBIT) released with $\mathrm{IP}_{3}$ are proposed to interact with the $\mathrm{IP}_{3} \mathrm{R}$ whereas binding of ERp44 confers redox sensing (Mikoshiba 2007). Like the $\mathrm{IP}_{3} \mathrm{R}$, ryanodine receptors (RyRs) are also massive tetrameric $(2.2 \mathrm{mDa})$ channels permeant to $\mathrm{Ca}^{2+}$ that span the ER or SR. The primary natural agonist of RyR is $\mathrm{Ca}^{2+}$, low $\left[\mathrm{Ca}^{2+}\right]_{\mathrm{i}}$ opens the channel to allow $\mathrm{Ca}^{2+}$ to flow out of the ER/SR whereas higher $\left[\mathrm{Ca}^{2+}\right]_{\mathrm{i}}$ near the openings of channel inhibits $\mathrm{Ca}^{2+}$ gating and thus prevents $\left[\mathrm{Ca}^{2+}\right]_{\mathrm{i}}$ overload. Approximately $80 \%$ of the RyR's mass is located towards cytoplasm, where it interacts with several proteins such as $\mathrm{Ca} / \mathrm{CaM} / \mathrm{CaMKII}$, FK-506-binding proteins, mAKAP/PKA, PR130/calcineurin, spinophilin, and sorcin. Several other proteins such as triadin, junctin, and calsequestrin also regulate $\mathrm{ER} \mathrm{Ca}^{2+}$ availability to the pore (Bers 2004). IP ${ }_{3} \mathrm{Rs}$ and/or RyRs are also sensitive to the redox status of cells, to nitric oxide/Snitrosylation, and to quinones/reactive oxygen species (Waring 2005).

\section{Calcium waves in signaling}

The release of $\mathrm{Ca}^{2+}$ from the ER is a nonlinear, cooperative process wherein $\mathrm{IP}_{3}$ binds to four receptor sites on the $\mathrm{IP}_{3} \mathrm{R}$, one on each subunit of the tetramer (Mikoshiba 2007). In both ER and SR, $\mathrm{IP}_{3} \mathrm{Rs}$ and RyRs are at first potentiated, then inhibited by $\mathrm{Ca}^{2+}$. Small perturbations in conditions, such as ambient $\left[\mathrm{Ca}^{2+}\right]_{\mathrm{i}}$, $\left[\mathrm{IP}_{3}\right]$, and various regulators can cause uncoordinated bursts of local release across a cell (called "sparks" for their appearance in $\mathrm{Ca}^{2+}$ imaging fluorescence microscopy (see Fig. 2; Guatimosim et al. 2002). The brief opening of these channels gives rise to localized pulses (Fig. 2) such as the sparks or blips and puffs (Cheng et al. 1993; Parker and Yao 1996; Yao et al. 1995). The appearance of sparks or blips and puffs results in increase in the $\left[\mathrm{Ca}^{2+}\right]_{\mathrm{i}}($ Bootman and Berridge 1996; Parker and Yao 1996). At higher levels of $\mathrm{IP}_{3}$, the blips grow into larger puffs that can act as initiation sites for the onset of $\mathrm{Ca}^{2+}$ waves (Fig. 2). If the $\mathrm{IP}_{3} \mathrm{R}$ are sufficiently sensitized, they will respond to the $\mathrm{Ca}^{2+}$ diffusing away from a puff site and thereby propagate the signal through a process of calcium-induced calcium release (CICR) as depicted in Fig. 2. These waves are the mechanisms that coordinate the release of $\mathrm{Ca}^{2+}$ by all the $\mathrm{IP}_{3} \mathrm{R}$. Therefore, increasing spark frequency can cascade and become regenerative and is seen as two- or three dimensional waves of changes in $\left[\mathrm{Ca}^{2+}\right]_{i}$ that propagate within cells (Fig.2). These $\mathrm{Ca}^{2+}$ waves can interact with each other and create spirals or annihilate each other. The information transmitted by these $\mathrm{Ca}^{2+}$ waves can arrive as a stimulus at the plasma membrane and is translated into intracellular $\mathrm{Ca}^{2+}$ oscillations (Falcke 2004). 
The smallest $\mathrm{Ca}^{2+}$ release events, blips (Parker et al. 1996), probably reflect random openings of single $\mathrm{IP}_{3} \mathrm{R}$ (Fig. 2). Larger events, puffs, lasting tens of milliseconds and restricted to a volume of $\sim 0.5 \mathrm{fl}$, reflect the almost simultaneous opening of a few $\mathrm{IP}_{3} \mathrm{Rs}$ within a cluster (Parker et al. 1996; Suhara et al. 2006). Several coordinated puffs can form oscillations and waves as shown in Fig. 2 (Falcke 2004). $\mathrm{Ca}^{2+}$ oscillations, therefore, depend upon both the spatial organization of $\mathrm{IP}_{3} \mathrm{Rs}$ and their regulation by $\mathrm{Ca}^{2+}$ although the links between $\mathrm{IP}_{3} \mathrm{R}$ activities and $\mathrm{Ca}^{2+}$ oscillations are not fully understood (Taylor and Laude 2002).

How are random molecular events such as blips and puffs orchestrated into global intracellular $\mathrm{Ca}^{2+}$ oscillations? It is generally assumed if many molecules are involved in these processes, the cell behaves like a continuously stirred reactor and the law of large numbers can be used to predict such $\mathrm{Ca}^{2+}$ oscillations (van Kampen 2001). Though most models of the dynamics of intracellular $\mathrm{Ca}^{2+}$ release use the law of large numbers yet it is not consistent with experimental analyses showing that global oscillations arise from $\mathrm{Ca}^{2+}$ waves initiated locally (Falcke 2004; Marchant and Parker 2001). Therefore, such a local initiation of $\mathrm{Ca}^{2+}$ waves is predicted to lead to stochastic oscillations because although each cell has many $\mathrm{IP}_{3} \mathrm{Rs}$ and $\mathrm{Ca}^{2+}$ ions, the law of large numbers does not apply to the initiating event which is restricted to very few $\mathrm{IP}_{3} \mathrm{Rs}$ due to steep $\mathrm{Ca}^{2+}$ concentration gradients (Falcke 2003, 2004).

The stochastic nature of the release of $\mathrm{Ca}^{2+}$ from internal calcium stores such as ER into the cytoplasm have been studied by several investigators (Cheng et al. 1993). All ion channels have certain properties such as open or closed, conducting or non-conducting, with opening and closing describable as Markov processes. The stochastic nature of $\mathrm{Ca}^{2+}$ release is nicely shown by the observed onset of whole-cell $\mathrm{Ca}^{2+}$ oscillations as $\left[\mathrm{IP}_{3}\right]$ is increased in Xenopus oocytes (Marchant and Parker 2001). While at low [ $\left.\mathrm{IP}_{3}\right]$, only puffs are observed because there is not enough $\mathrm{Ca}^{2+}$ released from a cluster to stimulate $\mathrm{Ca}^{2+}$ release from neighboring sites, therefore the $\mathrm{Ca}^{2+}$ transient is purely local (see Fig. 2). At moderately higher $\left[\mathrm{IP}_{3}\right]$, the amount of $\mathrm{Ca}^{2+}$ released from each $\mathrm{IP}_{3} \mathrm{R}$ increases, leading to formation of $\mathrm{Ca}^{2+}$ waves that emerge from a nucleation site. However, at moderate levels of [IP $\left.{ }_{3}\right]$, global events are rare and in many cases there are waves that progress only a short distance before dying out. However, at very high $\left[\mathrm{IP}_{3}\right]$, global $\mathrm{Ca}^{2+}$ waves are seen to occur regularly with a welldefined period.

The changes in the cytoplasmic $\mathrm{Ca}^{2+}$ can be defined as follows (Falcke 2004):

$$
\mathrm{d}\left[\mathrm{Ca}^{2+}\right]_{\mathrm{i}} / d t=J \text { rel }-J \text { uptake, }
$$

where $\left[\mathrm{Ca}^{2+}\right]_{\mathrm{i}}$ is the cytoplasmic concentration of $\mathrm{Ca}^{2+}$, Jrel is the $\mathrm{Ca}^{2+}$ flux (in units of concentration per unit time) into the cytoplasm through release from calcium stores and $J$ uptake is the flux of $\mathrm{Ca}^{2+}$ via uptake into the calcium stores. The $\mathrm{Ca}^{2+}$ release flux $J$ rel can be described by the following equation:

$$
J \text { rel }=g P O\left(\left[\mathrm{Ca}^{2+}\right]_{\mathrm{ER}}-\left[\mathrm{Ca}^{2+}\right]_{\mathrm{i}}\right),
$$

where $P$ o is the open probability, $g$ is the maximal conductance, and the $\mathrm{Ca}^{2+}$ channel driving force $\left[\mathrm{Ca}^{2+}\right]_{\mathrm{ER}}-\left[\mathrm{Ca}^{2+}\right]_{\mathrm{i}}$, is difference between ER calcium $\left[\mathrm{Ca}^{2+}\right]_{\mathrm{ER}}$ and cytoplasmic calcium $\left[\mathrm{Ca}^{2+}\right]_{i}$. To account for the stochastic and spatial nature of the receptors, a more accurate model can be described by the following equation: 


$$
\partial\left[\mathrm{Ca}^{2+}\right]_{\mathrm{i}} / \partial t=D \nabla^{2}\left[\mathrm{Ca}^{2+}\right]_{\mathrm{i}}+\Sigma_{k} \delta\left(x-x_{k}\right) J_{\text {rel }}^{k}-J \text { uptake, }
$$

where $J^{k}$ rel represents the release of calcium from the $k$ th release unit and $x_{k}$ represents the spatial location of single channels or small clusters of channels. $J^{k}$ rel can be described by the following equation:

$$
J_{\text {rel }}^{k}=g_{k} p_{k}\left(\left[\mathrm{Ca}^{2+}\right]_{\mathrm{ER}}-\left[\mathrm{Ca}^{2+}\right]_{\mathrm{i}}\right),
$$

where $p_{k}$ is a random variable with values 0 or 1 to indicate whether the release unit is closed or open. In presence of a very large number of $\mathrm{Ca}^{2+}$ release sites, $p_{k}$ can be replaced by the average open probability $P_{0}$ and thus obtain the whole-cell model in the limit that diffusion is large compared to the total size of the cell. However, these assumptions are not valid in many physiological situations, such as in oocytes and pancreatic beta cells (Sherman and Rinzel 1991). Although it is possible to use Monte Carlo simulations to describe the random behavior of $\mathrm{Ca}^{2+}$ release events, such computations may not provide correct answers in multicellular settings (Bugrim et al. 1997; Falcke 2003).

\section{Cell-to-Cell Signaling}

The $\mathrm{Ca}^{2+}$ signaling among cells can occur in two ways. In the first process, the cells can use gap junction (connexin) channels to communicate with one another (Rosselleo et al. 2009). In the second process, the cell-to-cell signaling is performed by transmitter-gated $\mathrm{Ca}^{2+}$ permeant ion channels such as NMDA, nicotinic, purinergic ionotropic channels. The opening of $\mathrm{CaV}$ can rapidly increase the local periplasmic $\left[\mathrm{Ca}^{2+}\right]$ resulting in triggering of protein-fusion complexes such as synaptotagmins and SNARE complexes, and fusion of vesicles containing transmitter molecules with the plasma membrane. These transmitter molecules such as ATP, acetylcholine, or glutamate that are released outside the cell could gate $\mathrm{Ca}^{2+}$-permeant channels namely $\mathrm{P} 2 \mathrm{X}$, nicotinic receptors, and NMDA receptors on adjacent cell membranes (Block et al. 2010; Jahn and Scheller 2006; Rosselleo et al. 2009; Sudhof 2004).

\section{Remodeling of $\mathrm{Ca}^{2+}$ signaling in cancer cell proliferation}

$\mathrm{Ca}^{2+}$ plays important role throughout the mammalian cell cycle such as in early $\mathrm{G}_{1}$, at the $\mathrm{G}_{1} / \mathrm{S}$, and $\mathrm{G}_{2} / \mathrm{M}$ transitions (Fig. 3). The expression of immediate-early genes in $\mathrm{G}_{1}$, such as $F O S, J U N$ and $M Y C$, and the retinoblastoma (RB1) phosphorylation at the $\mathrm{G}_{1} / \mathrm{S}$ boundary are regulated by $\mathrm{Ca}^{2+}$ (Pande et al. 1996; Takuwa et al. 1996). Similarly, the $\mathrm{Ca}^{2+}$ binding protein calmodulin $(\mathrm{CaM})$ plays crucial roles in cell cycle progression through $\mathrm{G}_{1}$ and mitosis (Kahl and Means 2003; Rasmussen and Means 1989). It has been shown that the cells can be arrested in $\mathrm{G}_{1}$ stage by inhibition of CaM kinase (CaMK) leading to loss of cyclin D1 (CCND1) expression, and inhibition of cyclin-dependent kinase 4 (CDK4) and CDK2 (Fig. 3). Another target of CaM, calcineurin also plays a major role in the cell cycle progression through $\mathrm{G}_{1}$ and $\mathrm{S}$ phases by regulating cAMP-responsive element binding protein 1 (CREB1) and NFAT (Kahl and Means 2004). In its inactive phosphorylated state, NFAT localizes in the cytoplasm, but following an increase in $\left[\mathrm{Ca}^{2+}\right]_{i}$, the activated calcineurin dephosphorylates NFAT, which then translocates to the nucleus and regulates expression of its target genes (see Fig. 4). The influx of $\mathrm{Ca}^{2+}$ through plasma membrane channels such as the store-operated channel ORAI1 as well as efflux of $\mathrm{Ca}^{2+}$ from the ER can activate calcineurin and NFAT signaling pathway for inducing changes in cell cycle gene expression (Fig. 4; Gwack et al. 2007). 
In prostate cancer, it has been shown that the increased expression of TRPV6, a constitutively active $\mathrm{Ca}^{2+}$ channel, resulted in increased $\mathrm{Ca}^{2+}$ entry and therefore enhanced NFAT activation (Lehen'kyi et al. 2007). TRPV6 expression in high-grade prostate cancer can therefore act as biomarker of prognosis (Fixemer et al. 2003). Similarly, the overexpression of a constitutively active NFATC1 mutant in 3T3-L1 fibroblasts induced the expression of MYC, cyclins D1 and D2 (CCND2) resulting in a transformed phenotype (Buchholz et al. 2006). Since cyclin E and E2F are transcriptional targets of MYC, the NFAT-MYC signaling pathway connecting calcineurin and $\mathrm{Ca}^{2+}$ is crucial in cell cycle and provides for a very important role of $\mathrm{Ca}^{2+}$ (see Fig. 4).

Although the $\mathrm{Ca}^{2+}$-dependent signaling mechanisms are frequently remodeled or deregulated in cancer cells, the lack of studies showing mutations in genes associated with the $\mathrm{Ca}^{2+}$ regulating proteins may indicate that remodeling of $\mathrm{Ca}^{2+}$ signaling could arise due to epigenetic changes in gene expression and/or post-translational changes (Table 1) in the properties of existing signaling components (Monteith et al. 2007; Saidak et al. 2009).

\section{Remodeling of $\mathrm{Ca}^{2+}$ signaling in cancer cell survival and death}

Several studies have shown higher levels of $\left[\mathrm{Ca}^{2+}\right]_{\mathrm{i}}$ in activation and execution of cell death (Szado et al. 2008). However, through increased expression of pro-survival signaling proteins such as the anti-apoptotic BCL2 family members and suppression of death signaling pathways, the cancer cell can survive in presence of death-inducing stimuli (Edinger and Thompson 2004; Hanahan and Weiberg 2000).

By virtue of regulating the levels of $\left[\mathrm{Ca}^{2+}\right]_{\mathrm{i}}$, the two organelles namely ER and mitochondria play crucial roles in $\mathrm{Ca}^{2+}$ signaling and deciding the ultimate fate of the cell. The same $\mathrm{Ca}^{2+}$ efflux from ER that is responsible for regulating processes for maintaining life, could act as a death-inducing signal at higher efflux of $\mathrm{Ca}^{2+}$ (Scorrano et al. 2003). It has been shown that in cells in which $\mathrm{IP}_{3} \mathrm{R}$ expression was either reduced or completely silenced, showed significantly less apoptosis (Jayaraman and Marks 1997). Similarly, the decrease in the level of basal $\mathrm{IP}_{3}$ also prevented cell death (Szado et al. 2008). The higher levels of $\left[\mathrm{Ca}^{2+}\right]_{\mathrm{i}}$ resulting due to increased efflux of $\mathrm{Ca}^{2+}$ from the $\mathrm{IP}_{3} \mathrm{R}$ activity, in turn can cause cell death through cytochrome $\mathrm{c}$ binding to $\mathrm{IP}_{3} \mathrm{R}$ or due to the activation of caspases (Aseefa et al. 2003). Similarly the activation of RyRs can generate increased levels of cytoplasmic $\mathrm{Ca}^{2+}$ that can participate in cell apoptosis (Hajnoczky et al., 2000). The targeting of mitochondrial networks by the proximity of $\mathrm{Ca}^{2+}$ signals arising from the ER can play important functions in cell death (Csordas et al., 2006).

In order for the cancer cells to proliferate at higher rates and still protect themselves from apoptosis, the cancer cells need to remodel the $\mathrm{Ca}^{2+}$ signaling machinery. Since ER and mitochondria play significant roles in the regulation of cell proliferation and apoptosis, the remodeling of $\mathrm{Ca}^{2+}$ signaling machinery in ER and mitochondria in cancer cells seems imminent during oncogenic transformation. In addition, in the cancer cells the increased expression of anti-apoptotic members of the BCL2 family of proteins, or decreased expression of the pro-apoptotic BH3-only proteins or BAX or BAK can protect these cells from apoptosis by modulating intracellular $\mathrm{Ca}^{2+}$ signals (Rong and Distelhorst 2008;

Scorrano et al. 2003). It has been shown that BCL2 family of proteins can decrease the level of $\mathrm{Ca}^{2+}$ fluxes from the ER either by binding to $\mathrm{IP}_{3} \mathrm{R}$ or by decreasing the $\mathrm{Ca}^{2+}$ content in the lumen of ER through inhibition of SERCA2 (Chen et al. 2004). In addition BCL2 can decrease the sensitivity of the mitochondrial $\mathrm{Ca}^{2+}$ uptake process as well as increasing their capacity to accumulate more $\mathrm{Ca}^{2+}$ (Danial and Korsmeyer 2004). Scorrano et al. (2003) have shown decreased level of ER $\mathrm{Ca}^{2+}$ and $\mathrm{Ca}^{2+}$ signals in apoptosis-resistant $\mathrm{Bax}$ - and $B a k$-knockout mouse embryonic fibroblasts. 


\section{Alterations in $\mathrm{Ca}^{2+}$ channels and pumps in cancer}

Since $\mathrm{Ca}^{2+}$ channels or pumps involved in regulating $\mathrm{Ca}^{2+}$ signaling pathways show altered expression in cancer, one can target these $\mathrm{Ca}^{2+}$ channels and pumps as therapeutic options to downregulate proliferation of cancer cells and enhance their apoptosis. Table 1 shows a comprehensive list of $\mathrm{Ca}^{2+}$ transport proteins such as specific isoforms of active transport $\mathrm{Ca}^{2+}$ pumps such as the PMCAs and the SERCAs and $\mathrm{Ca}^{2+}$ channels, including voltagegated and those of the TRP class and ATP-activated P2X ion channel family that are altered in cancer. The altered expression or activity of $\mathrm{Ca}^{2+}$ channels and pumps could either cause or promote cancers through modulation of $\mathrm{Ca}^{2+}$ concentrations in cytoplasm, ER/SR, and mitochondria as well as spatio-temporal nature of $\mathrm{Ca}^{2+}$ signaling (Berridge et al. 2003; Berridge 2009; Mikoshiba 2007). The overexpression of proteins such as $\mathrm{IP}_{3} \mathrm{R} \mathrm{Ca}^{2+}$ release channels that can cause an increase in $\mathrm{Ca}^{2+}$ leakage from the ER, thereby reducing the $\mathrm{Ca}^{2+}$ content of the ER $\mathrm{Ca}^{2+}$ stores or reduced sequestration of $\mathrm{Ca}^{2+}$ as a consequence of lower levels of SERCA2, could lead to decrease in the apoptotic rates (Rizzuto et al. 2003).

In addition, the $\mathrm{Ca}^{2+}$ channels and pumps can directly modify the transcription of genes and their products, e.g., the proteolytically cleaved $75 \mathrm{kDaC}$-terminal fragment of CaV1.2, an L-type voltage gated $\mathrm{Ca}^{2+}$ channel termed calcium channel associated transcriptional regulator or CCAT translocates to the nucleus and alters the transcription of several genes such as $M y c$, Bcl-associated death promoter ( $B a d$ ) and artemin (Gomez-Ospina et al. 2006). Nuclear CCAT protein levels increase or decrease in response to low and high intracellular $\mathrm{Ca}^{2+}$, respectively (Chung and Jan 2006; Gomez-Ospina et al. 2006). The isoform-specific upregulation of the mRNA and protein of the plasma membrane $\mathrm{Ca}^{2+}$ pump, PMCA4 leads to differentiation of a human colon cancer cell line (Aung et al. 2007). In colon cancer,

SERCA3 protein expression is either reduced or completely silenced compared with normal tissue resulting in a loss of differentiation in tumor cells (Gelebart et al., 2002). Similarly, as a result of decrease in SERCA2b expression, androgen-sensitive prostate cancer epithelial cells become androgen insensitive as a result of neuroendocrine differentiation process (Vanoverberghe et al. 2004).

\section{Therapeutic targeting of $\mathrm{Ca}^{2+}$ signaling in cancer}

In normal cells, the $\mathrm{Ca}^{2+}$ signaling is highly regulated spatially such as between ER and mitochondria, between PMCA and ER, including the spatial role played by the cytoskeletal elements and temporally in terms of $\mathrm{Ca}^{2+}$ oscillations and $\mathrm{Ca}^{2+}$ wave frequencies, amplitudes, and durations (Berridge et al. 2003; Rizzuto and Pozzan 2006; Berridge 1997). However, in cancer cells, such a spatio-temporal regulation of $\mathrm{Ca}^{2+}$ signaling is significantly modulated in terms of frequencies, amplitudes and duration of $\mathrm{Ca}^{2+}$ signals. Therefore, specific targeting of $\mathrm{Ca}^{2+}$ channels or pumps with restricted tissue distribution, altered expression in cancer and/or a role in the regulation of tumorigenic pathways, could specifically disrupt $\mathrm{Ca}^{2+}$ homeostasis in cancer cells. Treating both normal and cancer cells with an agent that disrupts these pathways may kill the cancer cell, owing to the loss of redundancy (Ding et al. 2010). One of the approaches in this direction involves selectively altering the activity of the $\mathrm{Ca}^{2+}$ channel or pump so as to inhibit $\mathrm{Ca}^{2+}$-dependent tumorigenic pathways such as in cell proliferation. It is also possible to exploit the altered expression of the $\mathrm{Ca}^{2+}$ channel or pump in cancer cells such as by using an activator of a PMCA that is overexpressed in a cancer cell, $\mathrm{Ca}^{2+}$ influx into the cell can then be increased that can lead to activation of cell death pathways and/or disruption of cell-cycle progression. Such a strategy has been adopted in the control of $\mathrm{LNCaP}$ prostate cancer cells by use of menthol as an activator of TRPM8 (Mahieu et al. 2007). In addition, by using inhibitors of pumps that either sequester $\mathrm{Ca}^{2+}$ into intracellular stores or increase $\mathrm{Ca}^{2+}$ efflux across the plasma membrane can lead to excessive $\left[\mathrm{Ca}^{2+}\right]_{\mathrm{i}}$ as well as excessive mitochondrial $\mathrm{Ca}^{2+}$ uptake resulting in cell death. An improved knowledge of the functioning of $\mathrm{Ca}^{2+}$ channels, 
pumps, and exchangers will help in treating cancer (Berridge 1997, 2003; Rizzuto and Pozzan 2006; Wang et al. 2010; Zhong et al. 2010).

\section{Conclusions}

The intracellular $\mathrm{Ca}^{2+}$ waves generated as a result of concerted activities of several cellular $\mathrm{Ca}^{2+}$ channels and pumps provides for a very effective and fast signaling that is needed at every step of the way in the day-to-day life of a living organism. The living cells have evolved to encode these $\mathrm{Ca}^{2+}$ waves as calcium code for information transfer in terms of the amplitude, duration, frequency, waveform or timing of $\mathrm{Ca}^{2+}$ oscillations that are then decoded at a later stage of signal transduction. In cancer cells, the altered expression of these $\mathrm{Ca}^{2+}$ channels and pumps cause alterations in $\mathrm{Ca}^{2+}$ wave characteristics resulting in a modified calcium code. Therefore, one can target these $\mathrm{Ca}^{2+}$ channels and pumps as therapeutic options to decrease cancer cell proliferation and increase cancer cell apoptosis. Such novel and highly innovative strategies can provide rationale and approaches for the design and development of novel technologies based on $\mathrm{Ca}^{2+}$ waves for the diagnosis and treatment of cancer.

\section{Supplementary Material}

Refer to Web version on PubMed Central for supplementary material.

\section{Acknowledgments}

The authors acknowledge the Florida International University Foundation's Faculty Research Award to J.P., and the Research Conference Awards from the National Institutes of Health, Flight Attendant Medical Research Institute, Society for Free Radical Research International and the Oxygen Club of California to K.A.

\section{References}

Amuthan G, et al. Mitochondrial stress-induced calcium signaling, phenotypic changes and invasive behavior in human lung carcinoma A549 cells. Oncogene. 2002; 21:7839-7849. [PubMed: 12420221]

Assefa Z, et al. Caspase 3induced truncation of type 1 inositol trisphosphate receptor accelerates apoptotic cell death and induces inositol trisphosphate independent calcium release during apoptosis. Journal of Biological Chemistry. 2004; 279:43227-43236. [PubMed: 15284241]

Aung CS, Kruger WA, Poronnick P, Roberts-Thomson SJ, Monteith GR. Plasma membrane $\mathrm{Ca}^{2+}$ ATPase expression during colon cancer cell line differentiation. Biochemical Biophysical Research Communication. 2007; 355:932-936.

Bentle MS, Reinicke KE, Bey EA, Spitz DR, Boothman DA. Calcium-dependent modulation of poly(ADP-ribose) polymerase-1 alters cellular metabolism and DNA repair. Journal of Biological Chemistry. 2006; 281:33684-33696. [PubMed: 16920718]

Berridge MJ. Inositol trisphosphate and $\mathrm{Ca}^{2+}$ signalling. Nature. 1993; 361:315-325. [PubMed: 8381210]

Berridge MJ. Unlocking the secrets of cell signaling. Annual Review of Physiology. 2005; 67:1-21.

Berridge MJ. Inositol trisphosphate and calcium signaling mechanisms. Biochimica et Biophysica Acta. 2009; 1793:933-940. [PubMed: 19010359]

Berridge MJ, Bootman MD, Roderick HL. Calcium signalling: dynamics, homeostasis and remodelling. Nature Reviews on Molecular and Cell Biology. 2003; 4:517-529.

Bers DM. Macromolecular complexes regulating cardiac ryanodine receptor function. Journal of Molecular Cell Cardiology. 2004; 37:417-429.

Bikle DD, Oda Y, Xie Z. Calcium and 1, 25(OH)2D: interacting drivers of epidermal differentiation. Journal of Steroid Biochemistry and Molecular Biology. 2004; 89-90:355-360. 
Block GJ, DiMattia GD, Prockop DJ. Stanniocalcin-1 regulates extracellular ATP-induced calcium waves in human epithelial cancer cells by stimulating ATP release from bystander cells. PLos One. 2010; 5(4):e10237. [PubMed: 20422040]

Bootman MD, Berridge MJ. Sub-cellular $\mathrm{Ca}^{2+}$ signals underlying waves and graded responses in HeLa cells. Current Biology. 1996; 6:855-865. [PubMed: 8805305]

Brouland JP, et al. The loss of sarco/endoplasmic reticulum calcium transport ATPase 3 expression is an early event during the multistep process of colon carcinogenesis. American Journal of Surgical Pathology. 2005; 167:233-242.

Buchholz M, et al. Overexpression of c-myc in pancreatic cancer caused by ectopic activation of NFATc1 and the $\mathrm{Ca}^{2+} /$ calcineurin signaling pathway. EMBO Journal. 2006; 25:3714-3724. [PubMed: 16874304]

Bugrim AE, Zhabotinsky AM, Epstein IR. Calcium waves in a model with a randomly spatially discrete distribution of $\mathrm{Ca}^{2+}$ release sites. Biophysical Journal. 1997; 73:2897-2906. [PubMed: 9414204]

Carafoli E. Special issue: calcium signaling and disease. Biochemical Biophysical Research Communication. 2004; 322:1097.

Carafoli E. Calcium signaling: a tale for all seasons. Proceedings of National Academy of Sciences USA. 2002; 99:1115-1122.

Chen R, et al. Bcl-2 functionally interacts with inositol 1, 4, 5-trisphosphate receptors to regulate calcium release from the ER in response to inositol 1, 4, 5- trisphosphate. Journal of Cell Biology. 2004; 166:193-203. [PubMed: 15263017]

Cheng H, Lederer WJ, Cannell MB. Calcium sparks: elementary events underlying excitationcontraction coupling in heart muscle. Science. 1993; 262:740-744. [PubMed: 8235594]

Chung FY, et al. Sarco/endoplasmic reticulum calcium- ATPase 2 expression as a tumor marker in colorectal cancer. American Journal of Surgical Pathology. 2006; 30:969-974. [PubMed: 16861967]

Chung HJ, Jan LY. Channeling to the nucleus. Neuron. 2006; 52:937-940. [PubMed: 17178398]

Clapham D. Calcium signaling. Cell. 2007; 131:1047-1058. [PubMed: 18083096]

Contassot E, et al. Arachidonylethanolamide induces apoptosis of human glioma cells through vanilloid receptor-1. Journal of Neuropathology and Experimantal Neurology. 2004; 63:956-963.

Cook SJ, Lockyer PJ. Recent advances in $\mathrm{Ca}^{2+}$ - dependent Ras regulation and cell proliferation. Cell Calcium. 2006; 39:101-112. [PubMed: 16343616]

Csordas G, et al. Structural and functional features and significance of the physical linkage between ER and mitochondria. Journal of Cell Biology. 2006; 174:915-921. [PubMed: 16982799]

Cullen PJ, Lockyer PJ. Integration of calcium and Ras signalling. Nature Reviews on Molecular and Cell Biology. 2002; 3:339-348.

Danial NN, Korsmeyer SJ. Cell death: critical control points. Cell. 2004; 116:205-219. [PubMed: 14744432]

Deeds J, Cronin F, Duncan LM. Patterns of melastatin mRNA expression in melanocytic tumors. Human Pathology. 2000; 31:1346-1356. [PubMed: 11112208]

De Koninck P, Schulman H. Sensitivity of CaM kinase II to the frequency of $\mathrm{Ca}^{2+}$ oscillations. Science. 1998; 279:227-230. [PubMed: 9422695]

DePaoli-Roach A, Roach PJ, Zucker KE, Smith SS. Selective phosphorylation of human DNA methyltransferase by protein kinase C. FEBS Letters. 1986; 197:149-153. [PubMed: 3949011]

Ding X, He Z, Zhou K, Cheng J, Yao H, Lu D, Cai R, Jin Y, Dong B, Xu Y, Wang Y. Essential role of TRPC6 channels in G2/M phase transition and development of human glioma. Journal of National Cancer Institute. 2010; 102:1052-1068.

Dolmetsch R. Excitation-transcription coupling: signaling by ion channels to the nucleus. Science STKE 2003, PE4. 2003

Dolmetsch RE, Lewis RS, Goodnow CC, Healy JI. Differential activation of transcription factors induced by $\mathrm{Ca}^{2+}$ response amplitude and duration. Nature. 1997; 386:855-858. [PubMed: 9126747] 
Dolmetsch RE, Xu K, Lewis RS. Calcium oscillations increase the efficiency and specificity of gene expression. Nature. 1998; 392:933-936. [PubMed: 9582075]

Edinger AL, Thompson CB. Death by design: apoptosis, necrosis and autophagy. Current Opinion on Cell Biology. 2004; 16:663-669.

Einstein A. Über die von der molekularkinetischen Theorie der Wärme geforderte Bewegung von in ruhenden Flüssigkeiten suspendierten Teilchen. Annalen der Physik. 1905; 17:549-560.

Endo Y, et al. Sarcoendoplasmic reticulum $\mathrm{Ca}^{2+}$-ATPase type 2 downregulated in human oral squamous cell carcinoma. International Journal of Cancer. 2004; 110:225-231.

Falcke M. On the role of stochastic channel behavior in intracellular $\mathrm{Ca}^{2+}$ dynamics. Biophysical Journal. 2003; 84:42-56. [PubMed: 12524264]

Falcke M. Reading the patterns in living cells- the physics of $\mathrm{Ca}^{2+}$ signalling. Advances in Physics. 2004; 53:255-440.

Fixemer T, Wissenbach U, Flockerzi V, Bonkhoff H. Expression of the $\mathrm{Ca}^{2+}$-selective cation channel TRPV6 in human prostate cancer: a novel prognostic marker for tumor progression. Oncogene. 2003; 22:7858-7861. [PubMed: 14586412]

Futreal PA, Wooster R, Stratton MR. Somatic mutations in human cancer: insights from resequencing the protein kinase gene family. Cold Spring Harbor Symposium on Quantitative Biology. 2005; 70:43-49.

Gelebart P, et al. Expression of endomembrane calcium pumps in colon and gastric cancer cells. Induction of SERCA3 expression during differentiation. Journal of Biological Chemistry. 2002; 277:26310-26320. [PubMed: 11986315]

Gerke V, Creutz CE, Moss SE. Annexins: linking $\mathrm{Ca}^{2+}$ signalling to membrane dynamics. Nature Reviews on Molecular and Cell Biology. 2005; 6:449-461.

Gomez-Ospina N, Tsuruta F, Barreto-Chang O, Hu L, Dolmetsch R. The C terminus of the L-type voltage gated calcium channel $\mathrm{Ca}(\mathrm{V}) 1.2$ encodes a transcription factor. Cell. 2006; 127:591-606. [PubMed: 17081980]

Goswami C, Kuhn J, Heppenstall PA, Hucho T. Importance of non-selective cation channel TRPV4 interaction with cytoskeleton and their reciprocal regulations in cultured cells. PLoS One 19. 2010; 5(7):e11654.

Gouaux E, Mackinnon R. Principles of selective ion transport in channels and pumps. Science. 2005; 310:1461-1465. [PubMed: 16322449]

Guatimosim S, Dilly K, Santana LF, Saleet Jafri M, Sobie EA, Lederer WJ. Local Ca ${ }^{2+}$ signaling and EC coupling in heart: $\mathrm{Ca}^{2+}$ sparks and the regulation of the $\left[\mathrm{Ca}^{2+}\right]_{\mathrm{i}}$ transient. Journal of Molecular Cell Cardioliology. 2002; 34:941-950.

Gwack Y, Feske S, Srikanth S, Hogan PG, Rao A. Signalling to transcription: store-operated $\mathrm{Ca}^{2+}$ entry and NFAT activation in lymphocytes. Cell Calcium. 2007; 42:145-156. [PubMed: 17572487]

Hajnoczky G, Csordas G, Madesh M, Pacher P. Control of apoptosis by IP3 and ryanodine receptor driven calcium signals. Cell Calcium. 2000; 28:349-363. [PubMed: 11115374]

Hanahan D, Weinberg RA. The hallmarks of cancer. Cell. 2000; 100:57-70. [PubMed: 10647931]

Heighway J, Betticher DC, Hoban PR, Altermatt HJ, Cowen R. Coamplification in tumors of KRAS2, type 2 inositol 1, 4, 5 triphosphate receptor gene, and a novel human gene, KRAG. Genomics. 1996; 35:207-214. [PubMed: 8661122]

Hilgemann DW, Yaradanakul A, Wang Y, Fuster D. Molecular control of cardiac sodium homeostasis in health and disease. Journal of Cardiovascular Electrophysiology. 2006; 17(Suppl 1):S47-S56. [PubMed: 16686682]

Huang JB, Kindzelskii AL, Clark AJ, Petty HR. Identification of channels promoting calcium spikes and waves in HT1080 tumor cells: their apparent roles in cell motility and invasion. Cancer Research. 2004; 64:2482-2489. [PubMed: 15059902]

Jaffe LF. A calcium based theory of carcinogenesis. Advances in Cancer Research. 2005; 94:231-263. [PubMed: 16096003]

Jahn R, Scheller RH. SNAREs-engines for membrane fusion. Nature Reviews on Molecular and Cell Biology. 2006; 7:631-643. 
Jayaraman T, Marks AR. T cells deficient in inositol 1, 4, 5-trisphosphate receptor are resistant to apoptosis. Molecular Cell Biology. 1997; 17:3005-3012.

Kahl CR, Means AR. Calcineurin regulates cyclin D1 accumulation in growth-stimulated fibroblasts. Molecular Biology of the Cell. 2004; 15:1833-1842. [PubMed: 14767060]

Kirichok Y, Krapivinsky G, Clapham DE. The mitochondrial calcium uniporter is a highly selective ion channel. Nature. 2004; 427:360-364. [PubMed: 14737170]

Korosec B, Glavac D, Rott T, Ravnik-Glavac M. Alterations in the ATP2A2 gene in correlation with colon and lung cancer. Cancer Genetics and Cytogenetics. 2006; 171:105-111. [PubMed: 17116488]

Kusner LL, Mygland A, Kaminski HJ. Ryanodine receptor gene expression thymomas. Muscle Nerve. 1998; 21:1299-1303. [PubMed: 9736058]

Latour I, et al. Expression of T-type calcium channel splice variants in human glioma. Glia. 2004; 48:112-119. [PubMed: 15378657]

Lazzeri M, et al. Transient receptor potential vanilloid type 1 (TRPV1) expression changes from normal urothelium to transitional cell carcinoma of human bladder. European Urology. 2005; 48:691-698. [PubMed: 15992990]

Lee WJ, et al. Expression of plasma membrane calcium pump isoform mRNAs in breast cancer cell lines. Cell Signal. 2002; 14:1015-1022. [PubMed: 12359307]

Lee WJ, Roberts-Thomson SJ, Monteith GR. Plasma membrane calcium-ATPase 2 and 4 in human breast cancer cell lines. Biochememical Biophysical Research Communication. 2005; 337:779783.

Lehen'kyi V, Flourakis M, Skryma R, Prevarskaya N. TRPV6 channel controls prostate cancer cell proliferation via $\mathrm{Ca}^{2+} /$ NFAT-dependent pathways. Oncogene. 2007; 26:7380-7385. [PubMed: 17533368]

Lewis RS. Calcium oscillations in T-cells: mechanisms and consequences for gene expression. Biochemical Society Transaction. 2003; 31:925-929.

Lewis RS. The molecular choreography of a store-operated calcium channel. Nature. 2007; 446:284287. [PubMed: 17361175]

Long SB, Campbell EB, MacKinnon R. Voltage sensor of Kv1.2: structural basis of electromechanical coupling. Science. 2005; 309:903-908. [PubMed: 16002579]

Mahieu F, et al. TRPM8-independent mentholinduced $\mathrm{Ca}^{2+}$ release from endoplasmic reticulum and golgi. Journal of Biological Chemistry. 2007; 282:3325-3336. [PubMed: 17142461]

Marchant J, Callamaras N, Parker I. Initiation of IP3-mediated $\mathrm{Ca}^{2+}$ waves in Xenopus oocytes. EMBO Journal. 1999; 18:5285-5299. [PubMed: 10508162]

Marchant J, Parker I. Role of elementary $\mathrm{Ca}^{2+}$ puffs in generating repetitive $\mathrm{Ca}^{2+}$ oscillations. EMBO Journal. 2001; 20:65-76. [PubMed: 11226156]

McLaughlin S, Murray D. Plasma membrane phosphoinositide organization by protein electrostatics. Nature. 2005; 438:605-611. [PubMed: 16319880]

Mikoshiba K. IP3 receptor/Ca ${ }^{2+}$ channel: from discovery to new signaling concepts. Journal of Neurochemistry. 2007; 102:1426-1446. [PubMed: 17697045]

Minaguchi T, Waite KA, Eng C. Nuclear localization of PTEN is regulated by $\mathrm{Ca}^{2+}$ through a tyrosil phosphorylation-independent conformational modification in major vault protein. Cancer Research. 2006; 66:11677-11682. [PubMed: 17178862]

Monteith GR, McAndrew D, Faddy HM, Roberts-Thomson SJ. Calcium and cancer: targeting $\mathrm{Ca}^{2+}$ transport. Nature Review on Cancer. 2007:519-530.

Munaron L, Fiorio PA. Endothelial calcium machinery and angiogenesis: understanding physiology to interfere with pathology. Current Medicinal Chemistry. 2009; 16:4691-4703. [PubMed: 19903140]

Pacifico F, et al. The expression of the sarco/ endoplasmic reticulum $\mathrm{Ca}^{2+}$-ATPases in thyroid and its down-regulation following neoplastic transformation. Journal of Molecular Endocrinology. 2003; 30:399-409. [PubMed: 12790808]

Pande G, Kumar NA, Manogaran PS. Flow cytometric study of changes in the intracellular free calcium during the cell cycle. Cytometry. 1996; 24:55-63. [PubMed: 8723903] 
Parekh AB, Penner R. Store depletion and calcium influx. Physiological Reviews. 1997; 77:901-930. [PubMed: 9354808]

Parker I, Choi J, Yao Y. Elementary events of InsP3- induced $\mathrm{Ca}^{2+}$ liberation in Xenopus oocytes: hot spots, puffs and blips. Cell Calcium. 1996; 20:105-121. [PubMed: 8889202]

Parker I, Yao Y. Ca ${ }^{2+}$ transients associated with openings of inositol trisphosphate-gated channels in Xenopus oocytes. Journal of Physiology (London). 1996; 491:663-668. [PubMed: 8815201]

Patton AM, Kassis J, Doong H, Kohn EC. Calcium as a molecular target in angiogenesis. Current Pharmaceutical Design. 2003; 9:543-551. [PubMed: 12570802]

Paz MF, et al. Genetic unmasking of epigenetically silenced tumor suppressor genes in colon cancer cells deficient in DNA methyltransferases. Human Molecular Genetetics. 2003; 12:2209-2219.

Petersen $\mathrm{OH}$. $\mathrm{Ca}^{2+}$ signalling and $\mathrm{Ca}^{2+}$-activated ion channels in exocrine acinar cells. Cell Calcium. 2005; 38:171-200. [PubMed: 16107275]

Pinton P, Rizzuto R. Bcl-2 and $\mathrm{Ca}^{2+}$ homeostasis in the endoplasmic reticulum. Cell Death Differentiation. 2006; 13:1409-1418.

Prakriya M, Lewis RS. Regulation of CRAC channel activity by recruitment of silent channels to a high open-probability gating mode. Journal of General Physiology. 2006; 128:373-386. [PubMed: 16940559]

Putney JW Jr. Capacitative calcium entry: sensing the calcium stores. Journal of Cell Biology. 2005; 169:381-382. [PubMed: 15866892]

Ramsey IS, Delling M, Clapham DE. An introduction to TRP channels. Annual Reviews of Physiology. 2006; 68:619-647.

Rasmussen CD, Means AR. Calmodulin is required for cell-cycle progression during G1 and mitosis. EMBO Journal. 1989; 8:73-82. [PubMed: 2469574]

Reisner PD, Brandt PC, Vanaman TC. Analysis of plasma membrane $\mathrm{Ca}^{2+}-\mathrm{ATPase}$ expression in control and SV40-transformed human fibroblasts. Cell Calcium. 1997; 21:53-62. [PubMed: 9056077]

Rey O, Young SH, Jacamo R, Moyer MP, Rozengurt E. Extracellular calcium sensing receptor stimulation in human colonic epithelial cells induces intracellular calcium oscillations and proliferation inhibition. Journal of Cell Physiology. 2010; 225:73-83.

Ribiczey $\mathrm{P}$, et al. Isoform-specific up-regulation of plasma membrane $\mathrm{Ca}^{2+}$-ATPase expression during colon and gastric cancer cell differentiation. Cell Calcium. 2007; 42:590-605. [PubMed: 17433436]

Ringer S. A further contribution regarding the influence of the different constituents of the blood on the contraction of the heart. Journal of Physiology. 1883; 4:29-42.3.

Rizzuto R, Pozzan T. Microdomains of intracellular $\mathrm{Ca}^{2+}$ : molecular determinants and functional consequences. Physiological Reviews. 2006; 86:369-408. [PubMed: 16371601]

Rizzuto R, et al. Calcium and apoptosis: facts and hypotheses. Oncogene. 2003; 22:8619-8627. [PubMed: 14634623]

Rong Y, Distelhorst CW. Bcl-2 protein family members: versatile regulators of calcium signaling in cell survival and apoptosis. Annual Review of Physiology. 2008; 70:73-91.

Rosenberger S, Thorey IS, Werner S, Boukamp P. A novel regulator of telomerase: S100A8 mediates differentiation-dependent and calcium-induced inhibition of telomerase activity in the human epidermal keratinocyte line HaCaT. Journal of Biological Chemistry. 2007; 282:6126-6135. [PubMed: 17197440]

Rossello RA, Wang Z, Kizana E, Krebsbach PH, Kohn DH. Connexin 43 as a signaling platform for increasing the volume and spatial distribution of regenerated tissue. Proceedings of National Academy of Sciences USA. 2009; 106:13219-13224.

Saidak Z, Mentaverri R, Brown EM. The role of the calcium-sensing receptor in the development and progression of cancer. Endocrinology Review. 2009; 30:178-195.

Saito K, et al. Plasma membrane $\mathrm{Ca}^{2+}$-ATPase isoform 1 down-regulated in human oral cancer. Oncology Report. 2006; 15:49-55. 
Sakakura C, et al. Possible involvement of inositol-1,4,5-trisphosphate receptor type 3 (IP3R3) in the peritoneal dissemination of gastric cancers. Anticancer Research. 2003; 23:3691-3697. [PubMed: 14666665]

Schmidt U, et al. Quantitative multi-gene expression profiling of primary prostate cancer. Prostate. 2006; 66:1521-1534. [PubMed: 16921506]

Scorrano L, et al. BAX and BAK regulation of endoplasmic reticulum $\mathrm{Ca}^{2+}$ : a control point for apoptosis. Science. 2003; 300:135-139. [PubMed: 12624178]

Sherman A, Rinzel J. Model for synchronization of pancreatic $\beta$-cells by gap junction coupling. Biophysical Journal. 1991; 59:547-559. [PubMed: 1646657]

Smith G, Dai L, Miura R, Sherman A. Asymptotic analysis of buffered calcium diffusion near a point source. SIAM Journal of Applied Mathematics. 2001; 61:1816-1838.

Sudhof TC. The synaptic vesicle cycle. Annual Reviews on Neurosciences. 2004; 27:509-547.

Suhara W, Kobayashi M, Sagara H, Hamadad K, Goto T, Fujimoto I, Torimitsu K, Mikoshiba K. Visualization of inositol 1,4, 5-trisphosphate receptor by atomic force microscopy. Neuroscience Letters. 2006; 391:102-107. [PubMed: 16198054]

Szado T, et al. Phosphorylation of inositol 1, 4, 5-trisphosphate receptors by protein kinase B/Akt inhibits $\mathrm{Ca}^{2+}$ release and apoptosis. Proceedings of National Academy of Sciences USA. 2008; 105:2427-2432.

Takuwa N, Zhou W, Kumada M, Takuwa Y. $\mathrm{Ca}^{2+}$-dependent stimulation of retinoblastoma gene product phosphorylation and $\mathrm{p} 34 \mathrm{cdc} 2$ kinase activation in serum-stimulated human fibroblasts. Journal of Biological Chemistry. 1993; 268:138-145. [PubMed: 8416921]

Taylor CW, Laude A. IP3 receptors and their regulation by calmodulin and cytosolic $\mathrm{Ca}^{2+}$ Cell Calcium. 2002; 32:321-334. [PubMed: 12543092]

Toyota M, Ho C, Ohe-Toyota M, Baylin SB, Issa JP. Inactivation of CACNA1G, a T-type calcium channel gene, by aberrant methylation of its 5' CpG island in human tumors. Cancer Research. 1999; 59:4535-4541. [PubMed: 10493502]

Tsavaler L, Shapero MH, Morkowski S, Laus R. Trp-p8, a novel prostate-specific gene, is upregulated in prostate cancer and other malignancies and shares high homology with transient receptor potential calcium channel proteins. Cancer Research. 2001; 61:3760-3769. [PubMed: 11325849]

van Kampen, NG. Stochastic Processes in Physics and Chemistry. North-Holland, Amsterdam, The Netherlands: 2001.

Vanoverberghe $\mathrm{K}$, et al. $\mathrm{Ca}^{2+}$ homeostasis and apoptotic resistance of neuroendocrine-differentiated prostate cancer cells. Cell Death and Differentiation. 2004; 11:321-330. [PubMed: 14685164]

Wang Q, Symes AJ, Kane CA, Freeman A, Nariculam J, Munson P, Thrasivoulou C, Masters JR, Ahmed A. A novel role for wnt/ca signaling in actin cytoskeleton remodeling and cell motility in prostate cancer. PLOS One. 2010; 5(5):e10456. [PubMed: 20454608]

Wang XT, et al. The mRNA of L-type calcium channel elevated in colon cancer: protein distribution in normal and cancerous colon. American Journal of Pathology. 2000; 157:1549-1562. [PubMed: 11073814]

Waring P. Redox active calcium ion channels and cell death. Archives of Biochemistry and Biophysics. 2005; 434:33-42. [PubMed: 15629106]

Weinstein IB. Cancer. Addiction to oncogenes - the Achilles heal of cancer. Science. 2002; 297:6364. [PubMed: 12098689]

Westheimer FH. Why nature chose phosphates. Science. 1987; 235:1173-1178. [PubMed: 2434996]

Whitfield JF. Calcium signals and cancer. Critical Reviews on Oncology. 1992; 3:55-90.

Yao Y, Choi J, Parker I. Quantal puffs of intracellular $\mathrm{Ca}^{2+}$ evoked by inositol trisphosphate in Xenopus oocytes. Journal of Physiology (London). 1995; 482:533-553. [PubMed: 7738847]

Zhang L, et al. Gene expression profiles in normal and cancer cells. Science. 1997; 276:1268-1272. [PubMed: 9157888]

Zhong Z, Yeow WS, Zou C, Wassell R, Wang C, Pestell RG, Quong JN, Quong AA. Cyclin D1/ cyclin-dependent kinase 4 interacts with filamin $\mathrm{A}$ and affects the migration and invasion potential of breast cancer cells. Cancer Research. 2010; 70:2105-2114. [PubMed: 20179208] 
Zhuang L, et al. Calcium-selective ion channel, CaT1, is apically localized in gastrointestinal tract epithelia and is aberrantly expressed in human malignancies. Laboratory Investigations. 2002; $82: 1755-1764$. 


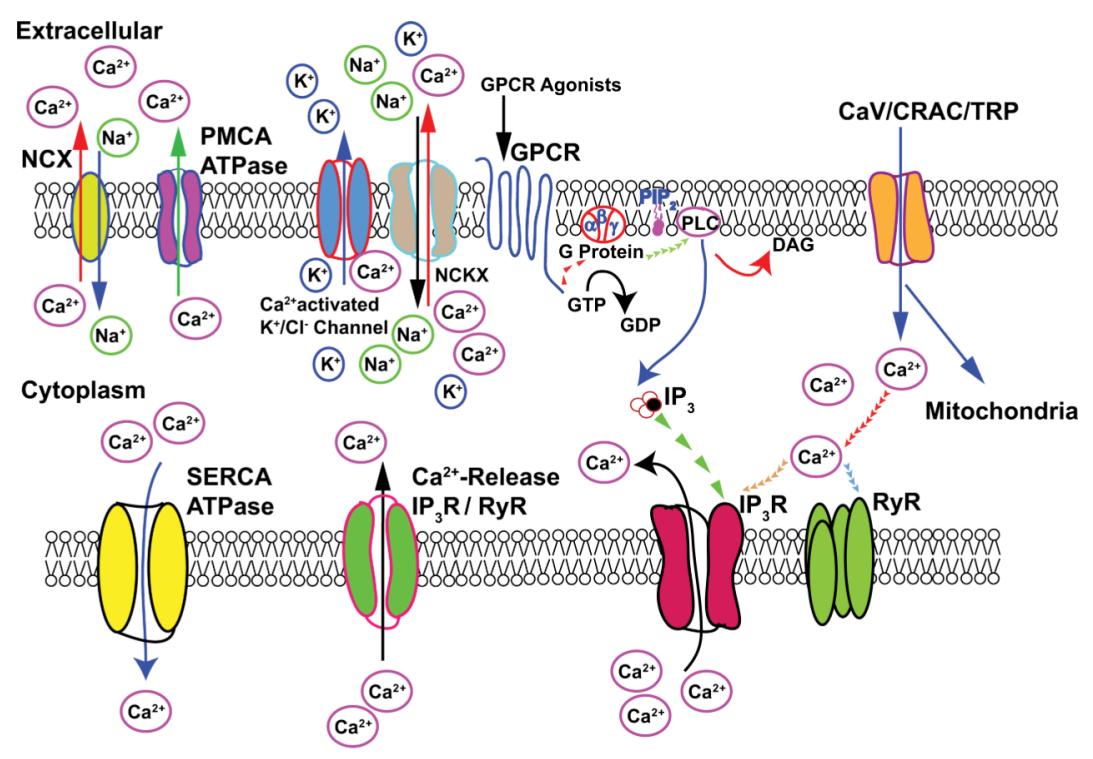

Endoplasmic Reticulum

Fig. 1.

$\mathrm{Ca}^{2+}$ signaling in cells. In resting cells the intracellular $\mathrm{Ca}^{2+}$ concentration, $\left[\mathrm{Ca}^{2+}\right]_{\mathrm{i}}$, is maintained at $\sim 100 \mathrm{nM}$ by $\mathrm{Ca}^{2+}$ removal via plasma membrane $\mathrm{Ca}^{2+}$ - ATPase (PMCA) and $\mathrm{Ca}^{2+}$ uptake into ER by SR $\mathrm{Ca}^{2+}$ - ATPase (SERCA) transporters. The $\mathrm{Na} / \mathrm{Ca}$ exchanger (NCX), a major secondary regulator of $\left[\mathrm{Ca}^{2+}\right]_{\mathrm{i}}$, is electrogenic, exchanging three $\mathrm{Na}$ ions for one $\mathrm{Ca}^{2+}$. Intracellular $\mathrm{Ca}^{2+}$ hyperpolarizes many cells by activating $\mathrm{K}+$ channels, and in some cells, $\mathrm{Cl}^{-}$channels. This decreases $\mathrm{CaV}$ channel activity but increases the driving force across active $\mathrm{Ca}^{2+}$-permeant channels. In excitatory $\mathrm{Ca}^{2+}$ signaling, plasma membrane ion channels are triggered to open by changes in voltage, or extra- or intracellular ligand binding. When open, $\sim 1$ million $\mathrm{Ca}^{2+}$ ions/s/channel flow down the 20000 fold $\mathrm{Ca}^{2+}$ gradient $(\mathrm{ECa} \sim+150 \mathrm{mV})$. Initial increase in $\left[\mathrm{Ca}^{2+}\right]_{\mathrm{i}}$ triggers more release, primarily from ER via $\mathrm{Ca}^{2+}$-sensitive RyR. GPCR or receptor tyrosine kinase-mediated activation of PLC cleaves PIP2 into $\mathrm{IP}_{3}$ and DAG. $\mathrm{IP}_{3}$ is a ligand for the intracellular $\mathrm{IP}_{3} \mathrm{R}$ channel spanning the membrane of the ER. GPCRs catalyze the exchange of GDP for GTP on G $\alpha$ subunits, releasing active $\mathrm{G} \alpha$ and $\mathrm{G} \beta \gamma$ subunits that in turn activate PLC $\beta$. 

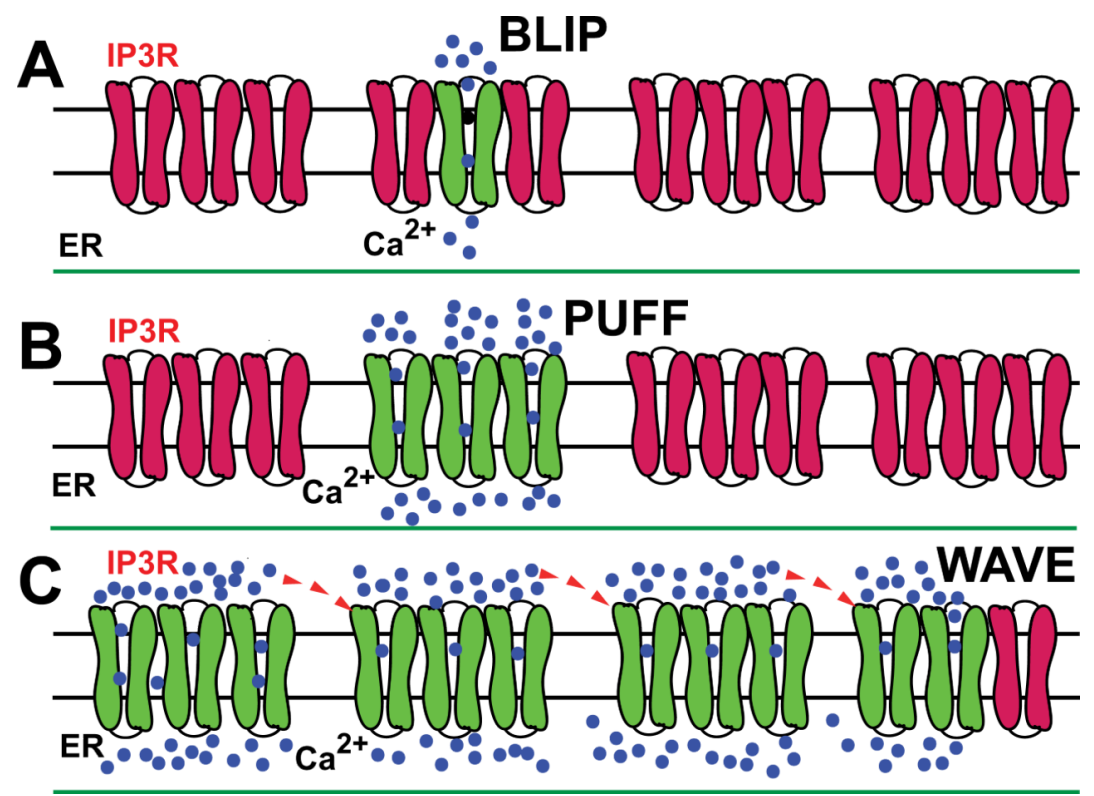

FIG. 2.

Elementary and global events of calcium signaling by IP3 in a dose-dependent manner. Inositol trisphosphate receptors (IP3R) are shown arranged in clusters that form $\mathrm{Ca}^{2+}$ release sites in the ER. A: at low $\mathrm{IP}_{3}$ concentration, a small number of $\mathrm{IP}_{3} \mathrm{R}$ (shown in green) release $\mathrm{Ca}^{2+}$ (shown in blue) into the cytoplasm as elementary event called "blip" whereas others $\mathrm{IP}_{3} \mathrm{R}$ (shown in dark red) are not bound with $\mathrm{IP}_{3}$ and therefore are not active. $B$ : at intermediate concentration of $\mathrm{IP}_{3}$, a group of $\mathrm{IP}_{3} \mathrm{R}$ opens to release $\mathrm{Ca}^{2+}$ to form "puff" which remains local because the neighboring $\mathrm{IP}_{3} \mathrm{Rs}$ are not active. $\mathrm{C}$ : at higher concentrations of $\mathrm{IP}_{3}$, the activation of a large number of $\mathrm{IP}_{3} \mathrm{R}$ leads to formation and global propagation of $\mathrm{Ca}^{2+}$ waves. $\mathrm{Ca}^{2+}$ released at one cluster can trigger $\mathrm{Ca}^{2+}$ release at adjacent clusters by calcium-induced calcium release (CICR) that leads to the formation of $\mathrm{Ca}^{2+}$ waves which propagate by successive cycles of $\mathrm{Ca}^{2+}$ release, diffusion, and CICR. 


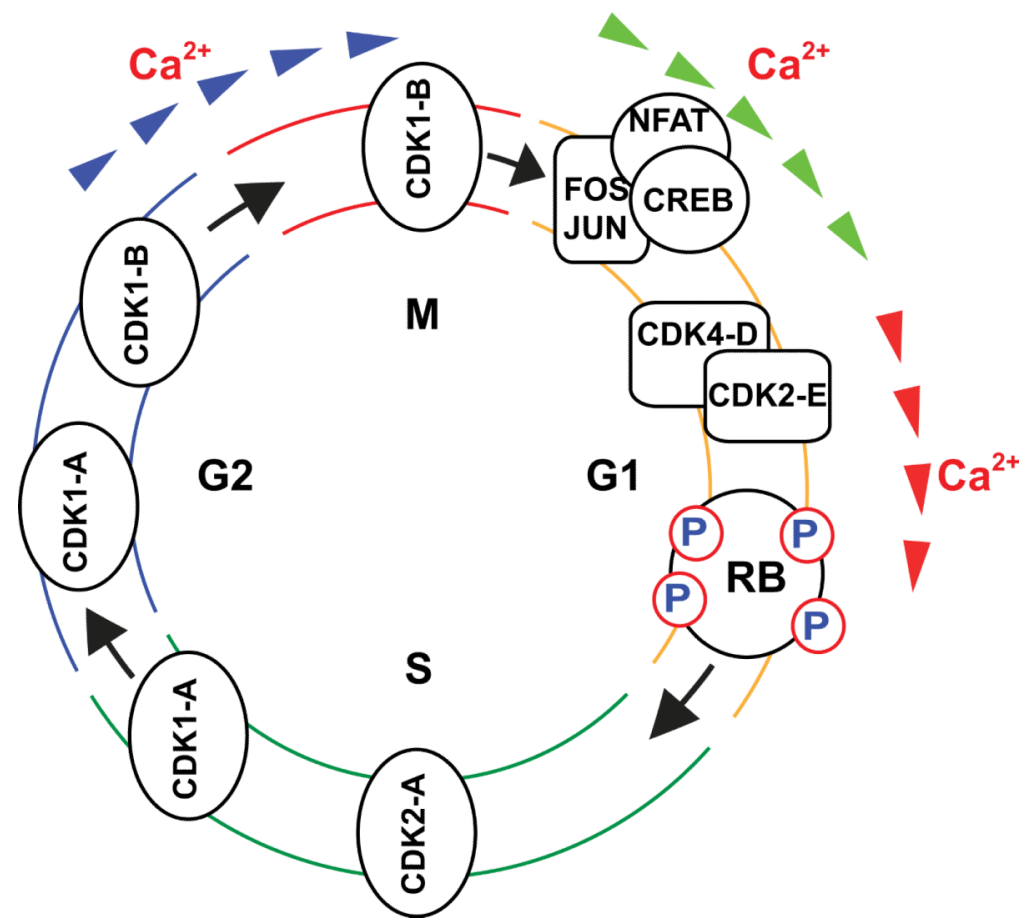

Fig. 3.

Regulation of cell cycle by $\mathrm{Ca}^{2+}$. $\mathrm{Ca}^{2+}$ signaling at various key stages of the cell cycle plays crucial roles such as the activation and expression of transcription factors FOS and JUN, CREB) and NFAT as the cells enter the G1 phase. These transcription factors in turn regulate the D-type cyclins, required for activation of cyclin D-CDK4 complexes (D-K4). Later in G1 phase of cell cycle, $\mathrm{Ca}^{2+}$ plays an important role in the activity of D-K4 and E$\mathrm{K} 2$ complexes required for phosphorylation and consequently inactivation of retinoblastoma (RB) that causes cells to progress to $S$ phase. During the $\mathrm{G}_{1} / \mathrm{S}$ and $\mathrm{G}_{2} / \mathrm{M}$ transitory phases of cell cycle, the $\mathrm{Ca}^{2+}$ oscillations play important roles in centrosome duplication, maturation, and separation in cytokinesis. 


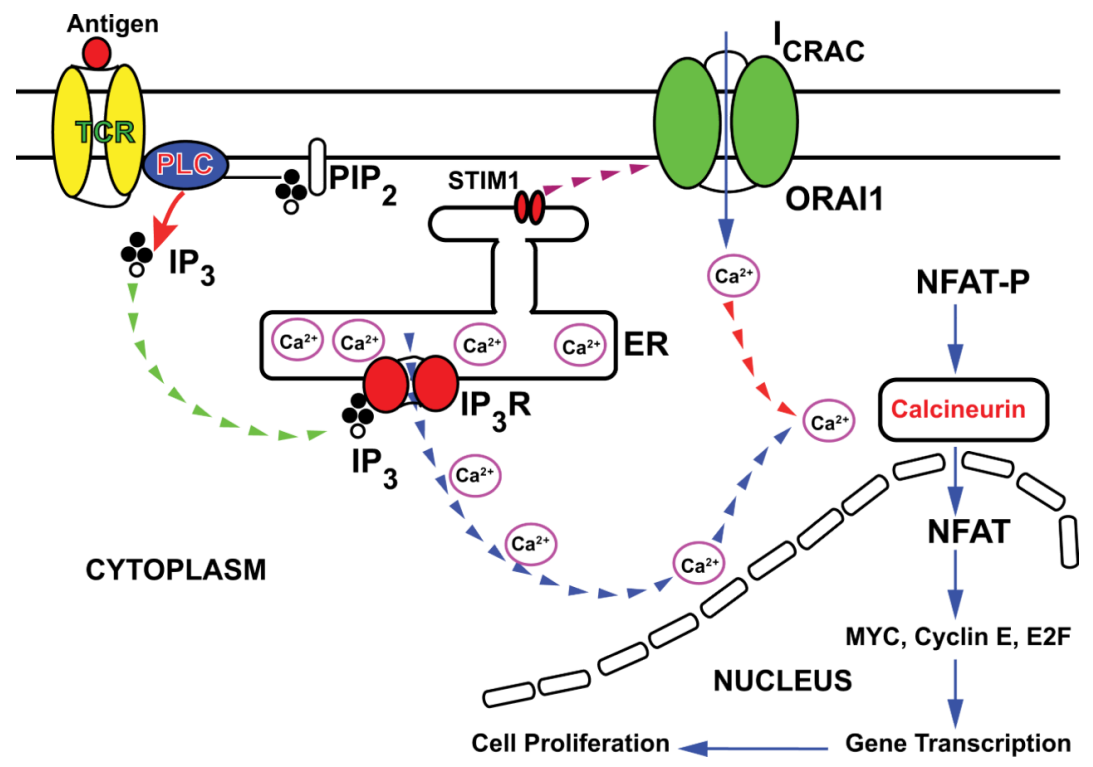

Fig. 4.

$\mathrm{Ca}^{2+}$ waves activate transcription factor NFAT that in turn controls cell cycle. The changes in $\mathrm{Ca}^{2+}$ waves oscillation frequency can activate transcription factors such as transcription factor NFAT resulting in regulation of cellular transcription. Calcineurin plays a major role in the cell cycle progression through $\mathrm{G}_{1}$ and $\mathrm{S}$ phases by regulating CREB1 and the nuclear NFAT. In its inactive phosphorylated state, NFATs localizes in the cytoplasm, but following an increase in $\left[\mathrm{Ca}^{2+}\right]_{\mathrm{i}}$, the activated calcineurin dephosphorylates NFAT which then translocates to the nucleus and regulates expression of its target genes. The influx of $\mathrm{Ca}^{2+}$ through plasma membrane channels such as the store-operated channel ORAI1 as well as efflux of $\mathrm{Ca}^{2+}$ from the ER can activate calcineurin and NFAT signaling pathway for inducing changes in cell cycle gene expression. Experiments using the "calcium clamp" have shown that the sensitivity of different transcription factors to $\left[\mathrm{Ca}^{2+}\right]_{i}$ oscillations is highly frequency dependent. 
Table 1

The changes in the expression of $\mathrm{Ca}^{2+}$ channels and pumps in cancer.

\begin{tabular}{|c|c|c|c|c|}
\hline $\mathrm{Ca}^{2+}$ Channel/pump & Type of Cancer & mRNA level & Protein level & Reference \\
\hline \multicolumn{5}{|l|}{ A. SERCA Pumps } \\
\hline \multirow[t]{4}{*}{ 1. SERCA2 } & Colon and Lung cancer & $\downarrow$ & ND & Korosec et al. 2006 \\
\hline & Thyroid cancer & $\downarrow$ & $\downarrow$ & Pacifico et al., 2003 \\
\hline & Oral cancer; squamous cell carcinoma & $\downarrow$ & $\downarrow$ & Endo et al., 2004 \\
\hline & Colorectal cancer & $\uparrow$ & ND & Chung et al., 2006 \\
\hline 2. SERCA3 & Colon cancer & ND & $\downarrow$ & Brouland et al.,2005 \\
\hline \multicolumn{5}{|l|}{ B. PMCA Pumps } \\
\hline 1. PMCA & Skin and lung cancer & ND & $\downarrow$ & Reisner et al., 1997 \\
\hline \multirow[t]{3}{*}{ 2. PMCA1 } & Oral cancer; squamous cell carcinoma & $\downarrow$ & $\downarrow$ & Saito et al., 2006 \\
\hline & Breast cancer & $\uparrow$ & ND & Lee et al., 2002 \\
\hline & Skin cancer & $\downarrow$ & ND & Reisner et al., 1997 \\
\hline 3. PMCA2 & Breast cancer & $\uparrow$ & ND & Lee et al., 2005 \\
\hline 4. PMCA4 & Skin cancer & $\downarrow$ & ND & Reisner et al., 1997 \\
\hline \multicolumn{5}{|l|}{ C. $I_{3} R / R y R s$} \\
\hline $\mathrm{IP}_{3} \mathrm{R} 2$ & Non-small-cell lung cancer & $\uparrow$ & ND & Heighway et al., 1996 \\
\hline $\mathrm{IP}_{3} \mathrm{R} 3$ & Gastric cancer & $\uparrow$ & $\uparrow$ & Sakakura et al.,2003 \\
\hline RyR1 & Thyoma & $\downarrow$ & ND & Kusner et al., 1998 \\
\hline \multicolumn{5}{|c|}{ D. Voltage-gated Channels } \\
\hline $\mathrm{Ca}_{\mathrm{V}} 1.2$ & Colon cancer & $\uparrow$ & ND & Wang et al., 2000 \\
\hline $\mathrm{Ca}_{\mathrm{V}} 1.1$ & Colorectal cancer & $\bar{\uparrow}$ & ND & Zhang et al., 1997 \\
\hline \multirow[t]{2}{*}{$\mathrm{Ca}_{\mathrm{v}} 3.1$} & Glioma & $\uparrow$ & ND & Latour et al., 2004 \\
\hline & Colorectal cancer & $\downarrow$ & ND & Toyota et al., 1999 \\
\hline $\mathrm{Ca}_{\mathrm{V}} 3.3$ & Colon cancer & $\downarrow$ & ND & Paz et al., 2003 \\
\hline \multicolumn{5}{|l|}{ E. TRP Channels } \\
\hline \multirow[t]{2}{*}{ TRPV1 } & Bladder cancer & ND & $\downarrow$ & Lazzeri et al., 2005 \\
\hline & Glioma & $\uparrow$ & $\uparrow$ & Contassot et al., 2004 \\
\hline \multirow[t]{2}{*}{ TRPV6 } & Prostate cancer & $\uparrow$ & ND & Fixemer et al., 2003 \\
\hline & Breast, ovary, thyroid, and colon cancers & $\uparrow$ & ND & Zhuang et al., 2002 \\
\hline TRPM1 & Melanoma & $\downarrow$ & ND & Deeds et al., 2000 \\
\hline \multirow[t]{2}{*}{ TRPM8 } & Prostate cancer & $\uparrow$ & ND & Schmidt et al., 2006 \\
\hline & Colorectal cancer & $\uparrow$ & ND & Tsavler et al., 2001 \\
\hline
\end{tabular}

